\title{
OBRIGAÇÃO COM CONVENÇÃO DE \\ PAGAMENTO EM \\ MOEDA ESTRANGEIRA
}

MARCELO SAMPAIO SIQUEIRA

Mestre em Direito pela Universidade Federal do Ceará. Especialista em Processo Civil pela Universidade de Fortaleza. Professor de Direito Civil na FA7 e na Faculdade Integrada do Ceará. Procurador do Município de Fortaleza. Advogado. msiqueira@veloxmail.com.br

Sumário: 1. Introdução; 2. O artigo 318 do Código Civil; 3. A questão da viabilidade; 4. Aquestão da inviabilidade; 5. Conclusão.

Resumo: O pagamento pactuado em moeda estrangeira, mas pago em moeda nacional, após a realização da devida conversão não pode ser considerado em face das normas do Código Civil de 2002, pois a execução do contrato em moeda nacional, mesmo que firmado em moeda estrangeira, não afasta a nulidade preconizada pelo artigo 318 do diploma civil de 2002. A alegação de prejuízo provocada pela invalidade da estipulação poderá ser reparada sob a fundamentação de enriquecimento sem causa.

Palavras-chave: Obrigação. Moeda estrangeira. Nulidade.

\section{INTRODUÇÃo}

O artigo jurídico que segue traz como tema um fato jurídico, cuja viabilidade deve ser analisada à luz do ordenamento com o fim precípuo de se estabelecer seu alcance.

Por um lado têm-se as leis, os usos ou outras fontes do direito, cabendo a consciência humana, utilizando-se das regras de hermenêutica, interpretar o fato à luz do ordenamento e extrair a conclusão do efeito jurídico. 
O fato é jurídico quando o evento, originário da vontade humana ou decorrente de fatos naturais, gera conseqüência na órbita do direito, criando, transformando, modificando ou extinguindo relações jurídicas. ${ }^{1}$

O saudoso professor cearense Clóvis Beviláqua, no seu livro Teoria Geral do Direito Civil ${ }^{2}$, citando Herman Post, entende por ciência geral do direito: "a exposição sistematizada de todos os fenômenos da vida jurídica da humanidade e a determinação de suas causas". Mais adiante o mestre afirma: "E como a vida jurídica, por um lado, se manifesta sob a forma de leis e usos jurídicos, e, por outro lado, é operação da consciência individual, a ciência geral do direito é, ao mesmo tempo sociológica e psicológica".

O aplicador do direito, ou seu operador, ao analisar o fato deverá valorá-lo, procurando interpretar sua validade e conseqüência perante regras jurídicas, que possuem diferenças perante as demais regras de natureza social.

No dizer de Cordeiro (2002, p.98):

As regras jurídicas distinguem-se das demais regras sociais, apenas, pela sua inclusão assumida num particular processo de decisão, ou seja: pela sua sujeição estrita à Ciência do Direito. Mas isso não absorve todas as regras. À necessidade de elementos suprapositivos soma-se o realismo no estabelecer das soluções: estas, fatalmente influenciadas pelos cenários culturais que presidem ao seu encontrar, apresentam sempre níveis éticos que não devem ser ignorados.

No final de 2004, em magistral aula no curso de doutoramento em ciências jurídicas na Faculdade de Direito da Universidade de Lisboa, o já citado Professor Doutor Antônio Menezes Cordeiro, titular da disciplina de Direito Civil, lecionou sobre o processo de realização do direito, informando a existência de várias fases: determinação da fonte; sua interpretação; integração de eventuais lacunas; a delimitação da matéria de fato; a sua qualificação jurídica e a aplicação.

A aceitação deste processo leva à conclusão de que o processo hermenêutico pode ser sistemático.

A intenção do presente artigo não é aprofundar estudos sobre teorias interpretativas, mas sim analisar uma relação jurídica de natureza obrigacional: a viabilidade de um contrato firmado no Brasil e a ser cumprido neste País por partes estabelecidas no território brasileiro ter como objeto prestação de pagar moeda estrangeira.

${ }^{1}$ Silvio Rodrigues. Direito Civil-Parte Geral. 2002, pág. 155/156.

${ }^{2}$ Apud Clovis Beviláqua, Teoria Geral do Direito Civil, 1955, pág. 09. 
Tomando por base a análise sistemática do problema, apresentam-se os seguintes tópicos ${ }^{3}$ : a) fonte (o negócio jurídico proposto no parágrafo anterior); b) interpretação (inteligência do negócio jurídico: é permitida obrigação pecuniária com fixação de pagamento em moeda estrangeira?); c) integração de eventuais lacunas (se houver); d) delimitação da matéria de fato (contratos estabelecidos e com local do pagamento fixado no Brasil); e) qualificação jurídica ( artigos do código Civil e legislação aplicável a espécie) e f) aplicação (plano da validade e eficácia).

A questão apresentada é interessante, e a justificativa para sua pesquisa é a reflexão sobre os artigos $318^{4}$ e $315^{5}$ do Código Civil, sobre as normas do Decreto Lei $n^{\circ} 857 / 69^{6}$ e da Lei 10.192/017, e sobre o entendimento do Superior Tribunal de Justiça, cujos julgados recentes ${ }^{8}$ entendem que é válida a contratação em moeda estrangeira, desde que o pagamento seja efetivado mediante a devida conversão em moeda nacional. ${ }^{9}$

A conclusão apresentada pelo citado Tribunal Superior é importante pois indica uma tendência da interpretação das regras citadas, cuja viabilidade desta linha de raciocínio se constitui a pergunta a ser respondida.

Se o objetivo da pesquisa é analisar a interpretação e a conclusão de uma linha jurisprudencial do Superior Tribunal de Justiça ${ }^{10}$, tornam-se necessárias algumas considerações sobre questões hermenêuticas.

3 Antônio Menezes Cordeiro. Introdução a edição portuguesa da obra Pensamento Sistemático e conceito de sistema na Ciência do Direito de Claus - Wilhelm Canaris. Fundação Calouste Gubenkian. 2002,pág.CI.

${ }^{4}$ Art. 318. São nulas as convenções de pagamento em outro ou em moeda estrangeira, bem como para compensar a diferença entre o valor desta e o da moeda nacional, excetuados os casos previstos na legislação especial.

5 Art.315. As dívidas em dinheiro deverão ser pagas no vencimento, em moeda corrente e pelo valor nominal, salvo o dispositivo nos artigos subseqüentes.

${ }^{6}$ Art. $1^{\circ}$. São nulos de pleno direito os contratos, títulos e quaisquer documentos, bem como as obrigações que, exeqüíveis no Brasil, estipulem pagamento em outro, em moeda estrangeira, ou, por alguma forma, restrinjam ou recusem, nos seus efeitos, o curso legal do cruzeiro.

7 Art. $1^{\circ}$. As estipulações de pagamento de obrigações pecuniárias exeqüíveis no território nacional deverão ser feitas em Real, pelo seu valor nominal.

Parágrafo único: são vedadas, sob pena de nulidade, quaisquer estipulações de:

I - pagamento expresso em, ou vinculados a outro o moeda estrangeira, ressalvado o disposto nos arts. $2^{\circ}$.

e $3^{\circ}$. Do Decreto-Lei no. 857, de 11 de setembro de 1969, e na parte final do art. $6^{\circ}$. da Lei no 8.880 , de 27 de maio de 1994.

8 AgRg no RESP 466801/RJ; RESP 33992/SP; RESP 361206/SP; RESP 194629/SP; AgRg no Ag 612405/MG.

${ }^{9}$ RESP $194629 /$ SP.

${ }^{10}$ EMENTA: PROCESSO CIVIL - AGRAVO DE INSTRUMENTO - NEGATIVA DE PROVIMENTO - AGRAVO REGIMENTAL - EMBARGOS DO DEVEDOR - MATÉRIA CONSTITUCIONAL SEDE IMPRÓPRIA - OFENSA AO ART. 535 DO CPC - INOCORRÊNCIA - NOTA PROMISSÓRIA EM MOEDA ESTRANGEIRA - ADMISSÃO - DATA DA CONVERSÃO DO VALOR DO TÍTULO - HONORÁRIOS ADVOCATÍCIOS - ART.20, §4 DO CPC - APRECIAÇÃO EQUITATIVA DO JUIZ - DESPROVIMENTO

“ 3 - No concernente à nulidade do título expresso em moeda estrangeira (art. $1^{\circ}$, do Decreto Lei 857/69; $1^{\circ}$ da MP 1675-55/98, convertida no art. $1^{\circ}$ da Lei 10.192/01 e art. 618, II do CPC), as alegações dos 
O artigo será dividido em três itens: I. a exegese do ordenamento aplicável à espécie, particularmente o artigo 318 do Código Civil de 2002; II. A teoria da viabilidade; III. a teoria da inviabilidade. Observa-se que esses itens se apresentam como objetivos específicos da pesquisa, visando a uma melhor ordenação das idéias e objetivando ao final apresentar resposta ao problema levantado.

\section{O artigo 318 do Código Civil}

A análise literal do artigo 318 do Código Civil coloca o operador do direito diante de uma vedação taxativa, não prevista pelo código de $1916^{11}$ : são nulas as convenções de pagamento em moeda estrangeira, bem como a utilização desta a título de atualização monetária, salvo os casos previstos em legislação especial.

O problema em tela traz um negócio jurídico obrigacional firmado no Brasil, para ser cumprido em território nacional, firmado entre partes capazes e legítimas, cujo objeto da obrigação constitui uma prestação de dar valor pecuniário fixado em moeda estrangeira. Logo, a discussão está no plano da validade e eficácia do negócio jurídico. Exemplificando: é possível uma pessoa natural, maior e capaz, alugar a uma outra, com igual característica jurídica, um imóvel residencial em Fortaleza, na Avenida Beira Mar, e ser ajustado no contrato um aluguel mensal em moeda européia?

Afirma-se de logo que não se constitui tarefa deste artigo analisar os contratos formados e firmados no Exterior e os casos excepcionais, como os tratados, por exemplo, no artigo $2^{\circ} .{ }^{12}$ do Decreto Lei 857/69. Informa-se também que a questão central desta pesquisa não é tão somente analisar a convenção de pagamento em moeda

recorrentes também não encontram respaldo na jurisprudência desta Corte Superior de Uniformização, porquanto neste aspecto, o v. acórdão decidiu em consonância com a orientação deste Tribunal e do Supremo Tribunal Federal, no sentido de que é legítimo o valor do título expresso em moeda estrangeira, desde que o pagamento efetive-se mediante a conversão em moeda nacional. E, conforme salientou o v. acórdão, em suas conclusões, os valores foram devidamente convertidos. Precedentes". (STJ. AgRg no Ag. 612405/MG, Relator Ministro Jorge Scartezzini, Quarta Turma, Data da publicação 22.08.2005, p.287).

${ }^{11}$ A vedação no entanto era prevista no Decreto Lei 857/69, artigo 1o., cujo texto é transcrito na nota 8 , e na lei 10.192 de 14 de fevereiro de 2001, artigo 1o., parágrafo único, inciso I.

${ }^{12}$ Art. 1o. São nulos de pleno direito os contratos, títulos e quaisquer documentos, bem como as obrigações que, exeqüíveis no Brasil, estipulem pagamento em ouro, em moeda estrangeira, ou, por alguma forma, restrinjam ou recusem, nos seus efeitos, o curso legal do cruzeiro.

Art. $2^{\circ}$. Não se aplicam as disposições no artigo anterior:

I - aos contratos e títulos referentes a importação ou exportação de mercadorias;

II - aos contratos de financiamento ou de prestação de garantias relativos às operações de exportação de bens de produção nacional, vendidos a crédito para o exterior;

III - aos contratos de compra e venda de câmbio em geral;

IV - aos empréstimos e quaisquer outras obrigações cujo credor ou devedor seja pessoa residente e domiciliada no exterior, excetuados os contratos de locação de imóveis situados no território nacional;

V - aos contratos que tenham por objeto a cessão, transferência, delegação, assunção, ou modificação das obrigações referidas no item anterior ainda que ambas as partes contratantes sejam pessoas residentes ou domiciliadas no país. 
estrangeira, mas também observar a validade e eficácia do negócio jurídico que tenha como objeto da obrigação a prestação fixada em moeda estrangeira.

O Professor Doutor Antônio Junqueira de Azevedo ${ }^{13}$ (2002, p.42-49) é categórico ao lecionar sobre as diferenças entre validade e eficácia do negócio jurídico:

A validade é, pois, a qualidade que o negócio deve ter ao entrar no mundo jurídico, consistente em estar de acordo com as regras jurídicas ("ser regular").

Em um outro capítulo o autor reitera:

O terceiro e último plano em que a mente humana deve projetar o negócio jurídico para examiná-lo é o plano da eficácia. Nesse plano, não se trata, naturalmente, de toda e qualquer possível eficácia prática do negócio, mas sim, tão-só, da sua eficácia jurídica e, especialmente, da sua eficácia própria ou típica, isto é, da eficácia referente aos efeitos manifestados como queridos. Feita essa advertência preliminar, e antes de tratarmos da situação normal, que é a da eficácia dos atos válidos, lembramos duas situações excepcionais: a eficácia do nulo e a ineficácia do válido. Ambas são, a nosso ver, provas cabais de que não se pode confundir válido com eficaz e nulo com ineficaz; não só há o ato válido ineficaz como, também, o nulo eficaz.

Partindo do pressuposto que o negócio jurídico retratado no problema lançado é existente ${ }^{14}$, passa-se agora a observar o plano da validade e eficácia do dito negócio, devendo estes planos serem analisados separadamente.

O plano da validade difere do da eficácia, pois o negócio jurídico pode ser válido e ineficaz $^{15}$, já a recíproca não é verdadeira. Isto é, salvo raras exceções ${ }^{16}$, não pode existir negócio jurídico inválido, mas eficaz.

A questão da validade não se confunde com a nulidade, mas o negócio inválido é nulo ${ }^{17}$ ou anulável. É neste prisma que se deve analisar o negócio jurídico proposto.

\footnotetext{
13 Antônio Junqueira de Azevedo. Negócio Jurídico existência, Validade e Eficácia. Saraiva, 2002, pág.42 e 49.

${ }^{14} \mathrm{O}$ Negócio jurídico proposto, locação de imóvel com pagamento de aluguel em moeda estrangeira, é existente pois estão presentes os elementos gerais: forma, objeto e declaração de vontade, além dos elementos gerais extrínsecos: tempo, lugar e agente.

${ }^{15}$ Como exemplo de negócio jurídico válido, mas ineficaz, são as obrigacionais condicionais suspensivas.

${ }^{16}$ Exemplo: artigo 1561. Embora anulável ou mesmo nulo, se contraído de boa-fé por ambos os cônjuges, o casamento, em relação a estes como aos filhos, produz todos os efeitos até o dia da sentença anulatória.

17 “os negócios jurídicos são nulos, em razão de causas que interessam ao direito privado, quando desobedecida a regra da incapacidade absoluta ou lhe faltar qualquer um dos demais requisitos legais de validade”. Fábio Ulhoa Coelho. Curso de Direito Civil, vol.1, Saraiva, 2005, fls.350.
} 
O fato apresentado, que trata de um contrato de locação, à luz do artigo 104 do Código Civil de 2002, traz: agentes capazes; objeto lícito (não é ilícito possuir moeda estrangeira); objeto possível (moeda estrangeira é um bem existente e passível de negociação); objeto determinado (a prestação é líquida). Logo, resta analisar de forma mais detalhada o inciso III, que trata da forma prescrita ou não defesa em lei, no tocante a validade e eficácia.

A infração a qualquer um desses itens torna o negócio jurídico inválido e conseqüentemente nulo ou anulável. A existência de forma prescrita ou não defesa em lei, expressa no novo Código Civil, que repete a regra do artigo 82 do Código passado, diz respeito à exteriorização da vontade, que poderá ser formal (escrita) ou informal (oral, gesto ou silêncio), e acarreta a invalidade do negócio se alguma forma exigida não estiver presente ou se o contrato possuir alguma forma vedada em lei.

A forma constitui um elemento a se observar no plano da validade. O professor Pedro Pais de Vasconcelos ${ }^{18}$ (2003.p.539), ao tratar sobre o assunto, com propriedade afirma:

O negócio jurídico torna-se reconhecível pela forma. A forma é o modo de exteriorização do acto ou do negócio jurídico, o modo como ele se torna aparente e reconhecível pelas pessoas perante quem se destina a vigorar.

A exteriorização do negócio jurídico, conhecida como a forma do contrato, no entanto não se pode confundir com as formalidades, que também têm importância no plano da validade, caso haja preterição de algo prescrito ou não defeso em lei.

As formalidades, no entanto, transcendem a forma, pois constituem requisitos acessórios de validade, e o descumprimento daquelas tornam o negócio jurídico nulo, sendo inválido, mesmo que a forma exigida tenha sido obedecida.

Citando-se mais uma vez o Professor Doutor Pedro Pais de Vasconcelos (2003. p.540), observa-se que a distinção ora tratada deve ser considerada pela doutrina:

Há na prática jurídica uma tendência para identificar ou mesmo confundir as formalidades com a forma, para inserir a forma no âmbito de um conceito amplo de formalidade, ou para incluir as formalidades num conceito alargado de forma. Mas é útil distinguir. A forma é o modo como o acto e o negócio se manifestam ou exteriorizam. As formalidades são actos acessórios, que estão funcionalmente ligados ao negócio mas que dele não fazem parte. Acompanham-no mas não se identificam com ele, nem são por ele englobados.

\footnotetext{
${ }^{18}$ Pedro Pais de Vasconcelos. Teoria Geral do Direito Civil. Almedina, 2003, pág.539
} 
Pode-se levar a crer que a questão abordada neste artigo, pagamento em moeda estrangeira relativa a negócio jurídico firmado e a ser executado no Brasil, encontra-se no campo da formalidade, já que a exteriorização do negócio jurídico tem o foco limitado à forma do contrato.

Os artigos 104 e 107 do código civil de 2002 falam da forma, mas não citam as formalidades como elemento de validade.

A preterição de alguma formalidade legal torna o ato nulo, sendo estes elementos categoriais de natureza inderrogável ${ }^{19}$.

A lei não exige no contrato de locação, utilizado como parâmetro nesta pesquisa, nenhuma forma predeterminada, mas a exteriorização da vontade possui alguns limites, como, por exemplo, a impossibilidade nos contratos de locação para uso residencial de se cobrar antecipadamente o aluguel mensal. Esta questão, que se constitui uma formalidade (pacto acessório), pode ser interpretada como algo defeso em lei ${ }^{20}$ (artigo 43, inciso III da Lei 8245/91).

O artigo 318 do Código Civil, cujo texto foi citado na nota 05 deste texto, traz uma vedação: cumprimento de uma obrigação mediante pagamento em moeda estrangeira, estipulação esta que pode constituir-se simultaneamente à própria formação do negócio jurídico.

No entanto, não se vislumbra que a fixação de uma estipulação, pagamento em moeda estrangeira de contrato firmado e a ser cumprido no Brasil, seja uma questão de forma ou formalidade, por dois aspectos básicos: a um, não se está discutindo a maneira de exteriorização do negócio relatado; a dois, a fixação de pagamento em moeda estrangeira não se configura um pacto acessório, nem uma solenidade.

$\mathrm{O}$ assunto, na opinião deste articulista, encontra-se tratado no artigo 166, inciso VII da nossa lei substantiva, que declara: é nulo o negócio jurídico quando: VII- a lei taxativamente declarar nulo, ou proibir-lhe a prática, sem cominar sanção. Logo a invalidade do negócio jurídico tratado poderia ser fundamentada neste plano.

A análise literal do texto da citada regra, artigo 318, cumulado com o artigo 166, inciso VII, ambos do Código Civil, deixa claro que o descumprimento ao preceito estabelecido leva à nulidade da estipulação, mas julgados recentes vêm declarando a validade do negócio jurídico, o que torna necessário a fixação da teoria da viabilidade ou da inviabilidade deste tipo de estipulação.

A dúvida persiste: o citado contrato de locação, que contenha a estipulação tratada, é nulo?

19 Vide: Antônio Junqueira de Azevedo. Negócio Jurídico, Saraiva, 2002, fls.43.

20 Além de ser um vício de forma, a existência desse pacto no negócio e a execução da mesma constituem uma contravenção penal. 


\section{A QUESTÃo DA VIABILIDADE}

Julgados recentes do Superior Tribunal de Justiça, cujos exemplos são citados na nota 9 deste artigo, aceitam a validade do negócio jurídico que pactua pagamento em moeda estrangeira, desde que este se efetive mediante conversão em moeda nacional.

O Código Civil de 1916 e o Código Comercial, movidos pelos ideais liberais, não estipulavam qualquer empecilho ao pagamento de obrigações em moeda estrangeira. A preocupação em se limitar as estipulações em questão começou a se manifestar com o surgimento das políticas econômicas, na década de 30 do século passado (Decreto 23.501 de 1933), visando o curso-forçado do papel-moeda circulante ${ }^{21}$.

Códigos estrangeiros, como o de Portugal e o da Espanha, não demonstram, neste assunto, a mesma preocupação dispensada pelo artigo 318 do Código Civil brasileiro de 2002. Sem dúvida alguma, as realidades econômicas são diferentes, mas naqueles diplomas continua a se consagrar a liberdade na pactuação do papel moeda em que se dará o cumprimento da prestação, podendo ser este diverso da moeda local.

O Código Civil Espanhol, no seu artigo 1170, $1^{\circ}$ parte, estipula: El pago de las deudas de dinero deberá hacerse em la espécie pactuaday, no siendo posible entregar la espécie, em la moneda de plata u oro que tenga curso legal em España.

$\mathrm{O}$ direito das obrigações na Espanha permite o cumprimento das estipulações pecuniárias em moeda estrangeira, determinando que o pagamento dessas prestações em moeda que tenha curso forçado na Espanha só se dará em caso de impossibilidade da entrega da moeda originariamente pactuada.

O Código Civil Português de forma mais complexa, no Livro II (Direito das Obrigações), Título I(Das obrigações em geral), capítulo III (modalidade das obrigações), Secção VI (Obrigações pecuniárias), trata tanto do princípio nominalista, artigo 55022, como das obrigações em moeda específica, artigos $552^{23}, 553^{24}$ e $554^{25}$.

${ }^{21}$ Ver sobre o assunto PEREIRA. Caio Mário da Silva. Instituições de direito civil, vol.II, Forense, 2004, páginas 131 a 141.

${ }^{122}$ Artigo $550^{\circ}$. Princípio nominalista $\mathrm{O}$ cumprimento das obrigações pecuniárias faz-se em moeda que tenha curso legal no País À data em que for efectuado e pelo valor nominal que a moeda nesse momento tiver, salvo estipulação em contrário

${ }^{23}$ Artigo $552^{\circ}$. Validade das obrigações de moeda específica $\mathrm{O}$ curso legal ou forçada da nota de banco não prejudica a validade do acto pelo qual alguém se comprometa a pagar em moeda metálica ou em valor dessa moeda.

${ }^{24}$ Artigo $553^{\circ}$. Obrigações de moeda específica sem quantitativo expresso em moeda corrente Quando for estipulado o pagamento em certa espécie monetária, o pagamento deve ser feito na espécie estipulada, existindo ela legalmente, embora tenha variado de valor após a data em que a obrigação foi constituída.

${ }^{25}$ Artigo $554^{\circ}$. Obrigações de moeda específica ou de certo metal com quantitativo expresso em moeda corrente Quando o quantitativo da obrigação é expresso em dinheiro corrente, mas se estipula que o cumprimento será efectuado em certa espécie monetária ou em moedas de certo metal, presume-se que as partes querem vincular-se ao valor corrente que a moeda ou as moedas do metal escolhido tinham à data da estipulação. 
A análise das regras transcritas em nota mostra que para o Direito Português não é nula a estipulação em moeda específica ou de certo metal, diferente da moeda portuguesa, presumindo-se que as partes querem vincular-se ao valor corrente que estas tenham em relação à moeda que tenha curso legal no país.

Fazer um estudo comparado do Direito peninsular é interessante, pois se trata de povo com cultura semelhante, dado os traços históricos advindos da colonização, embora que os artigos transcritos apenas evidenciem uma diferença entre as legislações, acentuando a dúvida, pois a regra do artigo 318 do Código Civil brasileiro possui regra restritiva, vedando inclusive a estipulação da compensação da diferença entre o valor da moeda específica pactuada e o da moeda nacional.

Nos tópicos anteriores dissecou-se acerca do fato jurídico objeto deste estudo, sendo importante ressaltar que a questão é de hermenêutica, cuja teoria sistemática foi citada na introdução, observando-se que a tendência jurisprudencial mencionada neste artigo foi construída com base no Código de 1916, cujo texto não proíbe o negócio, mas sob a égide do artigo $1^{\circ}$. do Decreto Lei 857/69 e artigo $1^{\circ}$. da Lei 10.192/01, existe regra proibitiva semelhante a observada no artigo 318 do novo Código Civil.

À primeira vista parece estranha a interpretação produzida pelo STJ, não aplicando a nulidade do negócio jurídico que estipula pagamento em moeda estrangeira, pois denotaria uma violação a expressa determinação legal. Fazendose uma análise dos julgados citados em notas, observa-se que a qualificação jurídica apresentada ao caso em estudo, dentro do processo sistemático, indica que: a) o pagamento pactuado em moeda estrangeira, após a realização da devida conversão, é realizado em moeda nacional; b) a nulidade do negócio jurídico traria proveito desmedido a uma das partes, que estaria tirando benefício da própria torpeza ou implicaria o enriquecimento injusto do devedor; c) o preço se ajustado em moedaestrangeira, mas em equivalência a certa quantidade de reais, não implica infração ao artigo 318 do Código Civil e as demais regras citadas.

O trabalho do hermeneuta ${ }^{26}$ no tema proposto é a busca do sentido da regra esculpida no artigo 318 do Código Civil, observando se a qualificação disposta no parágrafo anterior é passível de aceitação.

A questão é sem dúvida alguma de natureza hermenêutica. Se o interprete utilizarse da literalidade como ferramenta de interpretação, rapidamente concluiria que os julgados que apresentam esta motivação são equivocados.

A análise da questão a partir de agora deve ser tópica ${ }^{27}$, focando-se a regra do

\footnotetext{
26 "De todo modo, se a atividade ou o simples ato de captação do sentindo é interpretação, as regras pelas quais ela se opera e o entendimento de suas estruturas e do seu funcionamento, enfim, o entendimento dos seus labirintos é a Hermenêutica.” ( Raimundo Bezerra Falcão, Hermenêutica, Malheiros, 1997, pág.84.

27 "Em função disso, o Direito há de ser visto topicamente. Quer dizer, frente a um determinado problema, procurar-se-á sua solução; a seguir, a solução conseguida será apoiada em tópicos, consistentes em pontos de vista que pudessem ser compartilhados pela parte adversa na discussão, até que, admitidos esses pontos de vistasm ter-se-ia uma resposta lógica correta". (Raimundo Bezerra Falcão, Hermenêutica, Malheiros, 1997, pág. 179.
} 
artigo 318 do Código Civil e seus desdobramentos. Observa-se que a tópica não exclui o pensamento sistemático, ao contrário complementa- ${ }^{28}$.

O ponto nodal deste artigo é a análise dos argumentos apresentados pelas citadas jurisprudências do STJ, que não decretam a nulidade dos contratos que convencionam o pagamento em moeda estrangeira, mesmo estando vigente as regras do artigo $1^{\circ}$. do Dec. Lei $857 / 69$ e a do artigo $1^{\circ}$. da Lei 10.192/01, semelhante a regra existente no artigo 318 do Código Civil.

Para entender as conclusões dos citados julgados se faz necessário observar não só a fundamentação, mas também a motivação destes julgados.

Amotivação ${ }^{29}$, que deve existir nas decisões judiciais, consiste nos argumentos desenvolvidos pelo julgador para justificar a decisão. É com o acesso à motivação da decisão que as pessoas poderão conhecer as razões do julgador, permitindo a crítica doutrinária e o controle democrático sobre a atividade jurisdicional do Estado, evitando decisões arbitrárias e erradas. ${ }^{30}$

Esse princípio não vem explicitamente consagrado na Constituição de 1988, mas encontra-se, implicitamente, previsto no parágrafo $2^{\circ}$ do artigo $5^{\circ}$ da Constituição Federal, que determina: "Os direitos e garantias expressos nesta Constituição não excluem outros decorrentes do regime e dos princípios por ela adotados, ou dos tratados internacionais em que a República Federativa do Brasil seja parte."

O processualista Roberto $\operatorname{Rosas}^{31}$ expõe que "a importância da motivação da sentença cresce na Constituição italiana que a impõe expressamente (todas as decisões judiciais devem ser motivadas - art.111)". Adiante menciona que a Constituição brasileira não contém dispositivo idêntico, mas o princípio da motivação decorre do regime democrático e dos princípios inerentes a ele (Constituição, art. $5^{\circ}, \S 2$ ).

\footnotetext{
${ }^{28}$ Wilhelm Canaris Claus. Pensamento sistemático e conceito de sistema na ciência do direito. Lisboa. Fundação Calouste Gulbenkian, 2002, pág.273.

29 "Para o direito brasileiro a exigência da motivação vem das Ordenações Filipinas: "E para as partes saberem se lhes convém apelar ou agravar das sentenças definitivas, ou vir com embargos a elas, e os juízes da mor alçada entenderem melhor os fundamentos, por que os juízes inferiores se movem a condenar, ou absolver, mandamos que todos nossos Desembargadores, e quaisquer outros julgadores, ora sejam letrados, ora o não seja, declarem especificamente em suas sentenças definitivas, assim na primeira instância, como no caso da apelação ou agravo, ou revista, as causas, em que se fundaram a condenar ou absolver, ou a confirmar ou revogar"(Livro III, Título LXVI, $\S 7^{\circ}$ ).

"Essa regra Filipina foi para o regulamento 737 impondo ao juiz a motivação da decisão (art.232)".

"Os Códigos estaduais não fugiram a essa orientação, nem o nacional de 1939. No Código atual ela se apresenta em várias passagens: o juiz indicará, na sentença, os motivos que lhe formaram o convencimento (art.131) requisito essencial da sentença, que deve ser fundamentada (art.458,II), e até os despachos interlocutórios serão fundamentados, ainda que de modo conciso (art.165). A motivação é imposta ainda nos processos originários da competência dos tribunais." (Roberto Rosas. Direito Processual Constitucional, RT, 1997. Pág.46).

30 José de Albuquerque Rocha. Estudos sobre o Poder Judiciário, Malheiros, 1995. Pág.67.

${ }^{31}$ Roberto Rosas. Direito Processual Constitucional. 1997, pág.46.
} 
É com a motivação das decisões que as razões do convencimento do juiz são explicitadas, isto é, há a exteriorização dos motivos daquele posicionamento.

A fundamentação é um outro princípio processual constitucional, cujo enunciado difere substancialmente do princípio da motivação.

O Juiz, ao aplicar a norma jurídica pertinente à lide, resolve o conflito. $\mathrm{O}$ instrumento que põe fim à ação é justamente a sentença, que deverá conter, além dos requisitos constantes no Código de Processo Civil, a motivação, que são as conclusões emanadas pelo julgador para justificar a decisão, e a fundamentação, sujeição do juiz ao ordenamento jurídico como um todo ${ }^{32}$.

Ao contrário do princípio da motivação, a fundamentação vem expressamente prevista na Constituição Federal, inciso IX do art.93 da CF, e tem como finalidade, também, garantir as pessoas contra o arbítrio porventura cometido pelo judiciário.

Os julgados citados apresentam motivações díspares, mas todos eles validam o negócio jurídico em tela, não considerando a nulidade, que para os Ministros não se aplica à situação em estudo.

Passa-se agora a apresentação das argumentações observadas nos votos analisados:

a) o pagamento pactuado em moeda estrangeira, após a realização da devida conversão, é pago em moeda nacional ${ }^{33}$ - $O$ presente argumento leva em conta o fato de que o pagamento efetivo é feito em moeda nacional, embora deva guardar equivalência a certa quantidade de moeda estrangeira contratada. O contrato não desrespeita a regra legal se existir cláusula determinando que o valor fixado em moeda estrangeira, objeto da prestação, seja pago em moeda corrente nacional, em valor correspondente, na data do vencimento. O Ministro Sávio de Figueiredo Teixeira, em voto proferido em recurso indicado na nota 35 , afirma que "a finalidade do dispositivo (Decreto-Lei 857/69) consiste em inibir a restrição ou recusa do curso legal do cruzeiro, impondo, a contrario sensu, o seu curso forçado". Mais adiante motiva que: "o dólar americano foi tomado como parâmetro de mera atualização monetária, não havendo imposição contratual de

${ }^{32}$ José de Albuquerque Rocha. Estudos sobre o Poder Judiciário, Malheiros, 1995. Pág.67.

${ }^{33}$ EMENTA: CIVIL. CONTRATO DE CESSÃO DE DIREITO DE IMAGEM. CLUBE DE FUTEBOL. ATLETA PROFISSIONAL. CLÁUSULA CONTRATUAL QUE ATRELA AS CORREÇÕES MONETÁRIAS À VARIAÇÃO CAMBIAL DE MOEDA ESTRANGEIRA. PAGAMENTO EM MOEDA NACIONAL, COM BASE NA COTAÇÃO DE CÃMBIO. LEGALIDADE. DECRETOLEI N. 857/69, ART. $1^{\circ}$. EXEGESE. PRECEDENTES. AGRAVO DESPROVIDO.

- Na linha dos precedentes deste tribunal, é válida a contratação em moeda estrangeira, desde que o pagamento seja efetuado mediante a devida conversão em moeda nacional.

(AgRg no RESP 466801/RJ; Rel. Min. Sálvio de Figueiredo Teixeira, Quarta Turma, DJ.29.09.2003 p.258.) 
que a liquidação da obrigação devesse ocorrer em dólar". A interpretação desses aplicadores do direito é a de que a norma do artigo $1^{\circ}$, do Decreto Lei $n^{\circ} 857 / 69$, assemelhada a do artigo 318 , diz respeito tão somente à execução, que não pode ser efetuada em moeda estrangeira. Em síntese, não se veda a estipulação da prestação em moeda alienígena, desde que o pagamento se dê em moeda corrente nacional.

b) a nulidade do negócio jurídico traria proveito desmedido a uma das partes, que estaria tirando benefício da própria torpeza ou implicaria o enriquecimento injusto do devedor ${ }^{34}$ Essa motivação repele a nulidade do negócio jurídico pela questão da aparente injustiça que ocorreria entre os negociantes. Um dos princípios dos contratos é da boa-fé objetiva ${ }^{35}$, que ao contrário da boa-fé subjetiva, considera como modelo a ser observado uma conduta padrão de justiça aceitável para o caso, cujos preceitos transcendem ao aspecto literal da regra do artigo 318 do Código Civil (artigo $1^{\circ}$ do Dec. Lei. 857/69). A preocupação retratada nesse argumento está na possibilidade da efetivação de um contrato sinalagmático, no cumprimento da prestação por um e no descumprimento por parte do outro, que teria que pagar em moeda estrangeira, sob alegação de nulidade da pactuação face à ordem vigente. A viabilidade do pedido de nulidade traria uma situação de insegurança jurídica e de indiscutível injustiça sofrida por parte daquele que

${ }^{34}$ EMENTA: COMERCIAL - VALIDADE DE CONTRATO CELEBRADO EM MOEDA ESTRANGEIRA - PAGAMENTO EM CRUZEIRO - EXEGESE DA NORMA CONTIDA NO ART. $1^{\circ}$. DO DECRETO-LEI No $857 / 69$.

I - Legítimo é o pacto celebrado em moeda estrangeira, desde que o pagamento se efetive pela conversão em moeda nacional.

II - Alegação de nulidade do ajuste por suposta violação ao art. $1^{\circ}$. Do Decreto-Lei n $^{\circ} 857 / 69$, não favorece os partícipes na celebração do negócio porque estariam tirando proveito da própria torpeza.

III - O legislador visou evitar não a celebração de pactos ou obrigações em moedas estrangeiras, mas sim, aqueles que estipulassem o seu pagamento em outro valor que não o cruzeiro - moeda nacional recusando seus efeitos ou restringindo seu curso legal.

IV - Inteligência do art. $1^{\circ}$., do decreto-Lei no $857 / 69$, precedentes Resp's n ${ }^{\circ} \mathrm{s} 4.819-\mathrm{RJ}$ e 11.801-0-RJ $\mathrm{V}$ - Recurso não conhecido.

(RESP 36.120-6 - SP; Rel. Min. Waldemar Zveiter)

35 "Como o dispositivo do art. 421 se reporta ao que se denomina boa-fé objetiva, é importante que se distinga da boa-fé subjetiva. Na boa-fé subjetiva, o manifestante de vontade crê que sua conduta é correta, tendo em vista o grau de conhecimento que possui de um negócio. Para ele há um estado de consciência ou aspecto psicológico que deve ser considerado."

"A boa-fé objetiva, por outro lado, tem compreensão diversa. O intérprete parte de um padrão de conduta comum, do homem médio, naquele caso concreto, levando em consideração os aspectos sociais envolvidos. Desse modo, a boa-fé objetiva se traduz de forma mais perceptível como uma regra de conduta, um dever de agir de acordo com os determinados padrões sociais estabelecidos e reconhecidos." Silvio de Salvo Venosa. Direito Civil vol.II, Atlas, 2002, pág.379. 
concedeu a partida e não recebeu a contrapartida por questões formais, nulidade do contrato. Os defensores da viabilidade do negócio afirmam que a solução para evitar essa situação, em conformidade com a boa-fé, que deve existir entre os negociantes, é aceitar a validade do contrato, desde que o seu cumprimento se dê em moeda nacional. Logo, aplicar-se-ia a tese do item anterior, com o acréscimo do princípio citado, evitando-se injustiça e enriquecimento ilícito, artigo 884 do Código Civil ${ }^{36}$. De acordo com este argumento, a nulidade só poderia ser aceita se o contrato vergastado não possuir qualquer outra forma de cumprimento senão em moeda estrangeira.

c) o preço quando ajustado em moeda estrangeira, estipulando-se sua equivalência a certa quantidade de moeda nacional, não implica infração ao ordenamento jurídico. Esse argumento é um complemento da tese desenvolvida no item "a" e no item "b", cujo aplicador do direito, ao interpretar as normas citadas, defende: que o legislador não visou evitar a celebração de pactos ou obrigações em moedas estrangeiras, mas sim, a estipulação do seu pagamento em outro valor que não o cruzeiro moeda nacional-recusando seus efeitos ou restringindo seu curso legal. Mais uma vez informa-se que não existirá problema algum se a execução do contrato se dê em moeda nacional, cumprindo-se o espírito da norma que é conferir o curso forçado à moeda nacional.

Logo, há uma corrente importante do STJ que defende a teoria da viabilidade dos negócios jurídicos celebrados em moeda estrangeira, desde que o cumprimento da prestação se dê em moeda corrente nacional. Para os julgados apresentados, a correta exegese do artigo $1^{\circ}$. do Decreto-Lei 857/69 é que a nulidade do pactuado só ocorre se o credor exigir o cumprimento do pactuado em moeda estrangeira.

As três motivações afastam a nulidade tratada de forma imediata no artigo 318 e de forma mediata no artigo 166, VII, ambos do Código Civil, pois a nulidade seria apenas se ocorresse impossibilidade de se cumprir a prestação em moeda nacional.

É interessante agora tentar contrapor ou testar a tese defendida neste item, procurando fazer uma análise do artigo 318 do novo Código Civil e, ao final, concluir pela viabilidade ou inviabilidade.

\footnotetext{
${ }^{36}$ Art. 884. Aquele que, sem justa causa, se enriquecer à custa de outrem, será obrigado a restituir o indevidamente auferido, feita a atualização dos valores monetários.

Parágrafo único. Se o enriquecimento tiver por objeto coisa determinada, quem a recebeu é obrigado a restituíla, e, se, a coisa não mais subsistir, a restituição se fará pelo valor do bem na época em que foi exigido.
} 


\section{A QUESTÃo DA INVIABILIDADE}

O problema, com a vigência do artigo 318 do novo Código Civil, ganha nova conotação, pois a redação deste difere do artigo $1^{\circ}$. da Lei 10.192 e do $\operatorname{artigo~} 1^{\circ}$. do Decreto-Lei n ${ }^{\circ} 857 / 69$. O princípio em nossa opinião é o mesmo, mas a norma do novel código substantivo, além de reproduzir as normas antigas (As estipulações de pagamento de obrigações pecuniárias exeqüiveis no território nacional deverão ser feitas em real, pelo seu valor nominal - artigo $1^{\circ}$. Da Lei 10.192), acrescenta um aspecto novo: a vedação da compensação da diferença entre o valor da moeda estrangeira e o da moeda nacional.

A novidade citada introduz uma vedação importante que será objeto de análise neste item, mas inicialmente deve-se analisar o artigo $1^{\circ}$. do Decreto-Lei 857/69, que não é incompatível com a nova lei. O que ocorreu com a vigência do Novo Código Civil foi apenas o acréscimo de uma vedação.

Os julgados citados até agora neste artigo concluíram pela viabilidade do negócio jurídico em tela. A questão é complexa, pois existem opiniões em contrário, mesmo quando a fundamentação utilizada é a exegese do Decreto-Lei 857/69, que ainda se encontra vigente ${ }^{37}$.

Em voto proferido no REsp. 23.707-9/(MG ${ }^{38}$, o Excelentíssimo Ministro Athos Carneiro defende taxativamente a nulidade da cláusula que fixa preço em moeda estrangeira em contrato de compra e venda. A sua motivação está no fato de que a norma do artigo $1^{\circ}$. do Decreto-Lei 857/69, que veda esta estipulação, é de ordem pública e que dispor de forma diversa só poderia ocorrer nos casos do artigo $2^{\circ}$. do mesmo diploma, já que o contrato, discutido na ação, era inteiramente exeqüível no Brasil.

O jusfilósofo Miguel Reale ${ }^{39}$ (1987. p.131) ao lecionar sobre ordem pública grifou:

\footnotetext{
${ }^{37}$ Como o DL 857/69 continua vigente, as exceções nele previstas, no art. $2^{\circ}$., não serão afetadas pelo advento do CC, o qual, aliás, expressamente ressalva as previsões da lei especial. (Gustavo Tepedino. Código Civil Interpretado, Renovar, 2004, pág.319)

${ }^{38}$ EMENTA: CONTRATO DE COMPRA E VENDA, COM PREÇO FIXADO E INDEXADO EM DÓLARES, PARA PAGAMENTO EM CRUZEIROS. NULIDADE DA CLÁUSULA. DECRETOLEI 857/69.

É TAXATIVAMENTE VEDADAA ESTIPULAÇÃO, EM CONTRATOS EXEQÜÍVEIS NO BRASIL, DE PAGAMENTO EM MOEDA ESTRANGEIRA, A TANTO EQUIVALENDO CALCULAR A DÍVIDA COM INDEZAÇÃO AO DOLAR NORTE-AMERICANO, E NÃO A ÍNDICE OFICIAL OU OFICIOSO DE CORREÇÃO MONETÁRIA, LÍCITO SEGUNDO AS LEIS NACIONAIS.

AÇÃO DE COBRANÇA DA VARIAÇÃO CAMBIAL, PROPOSTA PELA VENDEDORA. NULIDADE DE PLENO DIREITO DA CLÁUSULA OFENSIVA A NORMA IMPERATIVA E DE ORDEM PÚBLICA.

RECURSO ESPECIAL CONHECIDO E PROVIDO.

(Resp 23707/MG, Rel. Min. Athos Carneiro, Quarta Turma, DJ.02.08.1993.)

${ }^{39}$ Miguel Reale. Lições preliminaries de direito, Saraiva, $15^{\circ}$.ed, pág. 131.
} 
O primeiro tipo de regras jurídicas que nos cumpre estudar são as chamadas regras jurídicas cogentes ou de ordem pública. A expressão de ordem pública tem trazido, infelizmente, várias confusões. $\mathrm{O}$ emprego do adjetivo pública leva, às vezes, alguns espíritos a confundir essas regras com as de Direito Público, que é aquele que rege as relações sociais em que de maneira imediata, prevalece o interesse da coletividade.

Ordem pública aqui está para traduzir a ascendência ou primado de um interesse que a regra tutela, o que implica a exigência irrefragável do seu cumprimento, quaisquer que sejam as intenções ou desejos das partes contratantes ou dos indivíduos a que se destinam. O Estado não subsistirá, nem a sociedade poderia lograr seus fins, se não existissem certas regras dotadas de conteúdo estável, cuja obrigatoriedade não fosse insuscetível de alteração pela vontade dos obrigados".

A caracterização da norma em discussão como de ordem pública é essencial, pois impede a disposição de forma diversa pela vontade das partes. Logo, segundo este importante voto, o contrato em análise é nulo, não podendo as partes dispor livremente do preceito em comento. Mas a pergunta que se faz nessa fase da pesquisa é se os argumentos levantados no item II deste artigo podem ser contraditados.

Em primeiro lugar, o pagamento pactuado em moeda estrangeira, mas pago em moeda nacional, após a realização da devida conversão não pode ser considerado, em face das normas anteriores ao Código Civil de 2002 e em face ao próprio Código, pois a execução do contrato em moeda nacional não afasta a nulidade preconizada, o que torna a estipulação inválida. O ponto nodal encontra-se no fato de que se permitir a validade do contrato é burlar o preceito legal que expressamente veda a pactuação. A conversão realizada funcionaria como uma cláusula de escala móvel (artigo 316 do Código Civil) indexada à moeda estrangeira, fato proibido pela Legislação Federal brasileira (Lei 6.423/7740) vigente à época, e hoje pelo próprio Código Civil, parte final do artigo 318.

Em segundo lugar, a nulidade do contrato não traria proveito desmedido a uma das partes, caso uma delas tenha cumprido com sua prestação. Em item anterior (1), discorreu-se sobre a questão da viabilidade e da eficácia do negócio jurídico, cuja conclusão é a que a inviabilidade, salvo exceções, traz a ineficácia do negócio jurídico. Imagine-se, mais uma vez, um contrato de locação de imóvel, cujo aluguel mensal é fixado em moeda estrangeira. Como ficaria o locador que concedesse

\footnotetext{
${ }^{40}$ Art. $1^{\circ}$. A correção, em virtude de disposição legal ou estipulação de negócio jurídico, da expressão monetária de obrigação pecuniária somente poderá ter por base a variação nominal da Obrigação do Tesouro Nacional - OTN.
} 
o uso e o gozo da coisa e no momento do recebimento do aluguel fosse surpreendido com a alegação de nulidade contratual, o que implicaria efeito ex tunc? Num primeiro momento poder-se-ia pensar que o locatário, que usou o bem, iria se beneficiar, pois não teria como ser cobrada sua retribuição neste tipo de contrato sinalagmático, em face da nulidade. Essa aparente injustiça não ocorrerá, pois o locador, diante da nulidade, poderá alegar enriquecimento sem causa da parte ex adversa e requerer a restituição do indevidamente auferido (artigo $884^{41}$ do Código Civil), evitando-se um locupletamento indevido. O Professor Venosa (2006. p.211) afirma com propriedade que:

"sempre que houver prejuízo econômico sem causa jurídica, haverá direito à ação de enriquecimento. Observemos, de plano, que o princípio não se confunde com indenização por perdas e danos. Não se está no campo da responsabilidade civil. A noção de culpa é irrelevante para o princípio geral".

É interessante observar que a norma citada é uma novidade do Código Civil de 2002, mas sem dúvida alguma o preceito estudado se constituía, no ordenamento anterior, um princípio geral do direito, e a impossibilidade de reaver o ganho injustamente auferido pelo devedor (inquilino) acarretaria no dever de restituir os ganhos, como medida de justiça $^{42}$, artigo 158 do Código Civil de 1916.

A tese ora defendida, além de juridicamente possível à luz do diploma civil antigo e do vigente, também está de acordo com o princípio da boa-fé objetiva ${ }^{43}$, pois o

\footnotetext{
${ }^{41}$ Art.884. Aquele que, sem justa causa, se enriquecer à custa de outrem, será obrigado a restituir o indevidamente auferido, feita a atualização dos valores monetários.

Parágrafo único. Se o enriquecimento tiver por objeto coisa determinada, quem a recebeu é obrigado a restituíla, e, se a coisa não mais subsistir, a restituição se fará pelo valor do bem na época em que foi exigido.

${ }^{42}$ Em que pese alguns julgados em contrário em nossa jurisprudência, na qual se sentiu falta de um dispositivo genérico sobre o enriquecimento indevido, a corrente majoritária, mormente em São Paulo, passou a admitir a ação de rito ordinário de enriquecimento, entre os principais coobrigados do título nessa situação (RT 443/214, 446/265, 441/134, 440/164, 442/265, 452/129, 468/223, 474/198, 175/197). Evidente que, sob tal premissa, vedar a ação in reverso é contrariar o princípio da eqüidade que rege o enriquecimento sem causa. É curial que a ação se desvincule dos princípios cambiários, regendo-se pelos requisitos do enriquecimento sem causa. Há que se provar os requisitos expostos. Silvio de Salvo Venosa. Direito Ciivl, vol.II. Atlas, 2006, pág.213.

43 "Denota-se, portanto, que a boa-fé é tanto forma de conduta (subjetiva ou psicológica) como norma de comportamento (objetiva). Nesta última acepção, está fundada na honestidade, na retidão, na lealdade e na consideração para com os interesses do outro contraente, especialmente no sentido de não lhe sonegar informações relevantes a respeito do objeto e conteúdo do negócio." "A boa-fé objetiva constitui um modelo jurídico, na medida em que se reveste de variadas formas. Não é possível catalogar ou elencar, a priori, as hipóteses em que ela pode configurar-se, porque se trata de uma norma cujo conteúdo não pode ser rigidamente fixado, dependendo sempre das concretas circunstâncias do caso. No entanto, essa imprecisão se mostra necessária, num sistema aberto, para que o intérprete tenha liberdade de estabelecer o seu sentido e alcance em cada caso". Carlos Roberto Gonçalves. Direito Civil Brasileiro III volume, Saraiva, 2004, pág.35/36.
} 
ressarcimento do locador, segundo o exemplo apresentado, que deseja receber a retribuição contratada, é a conduta aceitável pelos padrões sociais, evitando-se assim o seu prejuízo. É bem verdade que o seu ressarcimento não se dará pela cobrança da prestação anteriormente ajustada, mas por intermédio de um outro remédio jurídico, fundamentado no citado artigo 884 do Código Civil. Logo, não se deve aceitar o argumentado apresentado no item anterior.

Em terceiro lugar, o preço quando ajustado em moeda estrangeira, estipulando-se sua equivalência a certa quantidade de moeda nacional, implica infração ao ordenamento jurídico. Aceitar a tese contrária é concordar com a indexação da prestação pecuniária à variação cambial, tendo com base moeda estrangeira, fato vedado anteriormente pela Lei 6.423/77 e atualmente pelo artigo 318 do Código Civil. Aceitar que é válido o negócio jurídico se o pagamento se der em moeda corrente nacional tendo como parâmetro moeda estrangeira é indubitavelmente utilizar a variação da moeda estrangeira como indexador, fato que acarretaria também a nulidade da avença.

A regra do artigo $315^{44}$ do Código Civil, cujo artigo correspondente no Código civil de 1916 era o 947, indica que qualquer dívida pecuniária deverá ser paga no vencimento e em moeda corrente. Esta regra não afasta a aplicação do artigo 318, ao contrário o completa. Ressalta-se também que ela não pode ser usada para tornar válido o negócio retratado neste artigo, pois o pagamento em moeda nacional de contrato firmado em moeda estrangeira levaria a indexação do contrato a esta moeda, cuja vedação foi exposto no parágrafo anterior.

A oposição aos três argumentos levantados no item anterior leva o hermeneuta a concluir pela inviabilidade, já que existe norma expressa que veda a estipulação da prestação em moeda estrangeira e, mesmo que o pagamento ocorra em moeda nacional, não muda a ordem emanada na norma, pois a sua permissão implicaria no mínimo numa indexação do objeto da prestação à variação cambial, representada pela cotação da moeda alienígena.

A nulidade dos contratos com prestação pecuniária em moeda estrangeira é patente, e o fato da execução se dá em moeda nacional não desvirtua este absurdo jurídico. É importante, no entanto, verificar a questão com mais acuidade, pois a nulidade indicada e a vedação à ocorrência de qualquer efeito podem gerar injustiça ou até enriquecimento sem causa. O já citado professor Azevedo (2002. p.66), afirma:

Tanto dentro de cada plano quanto nas relações entre um plano e outro há um princípio fundamental que domina toda a matéria da inexistência,

\footnotetext{
${ }^{44}$ Art. 315. As dívidas em dinheiro deverão ser pagas no vencimento, em moeda corrente e pelo valor
} nominal, salvo o disposto nos artigos subseqüentes. 
invalidade e ineficácia; queremos referir-nos ao princípio da conservação. Por ele, tanto o legislador quanto o intérprete, o primeiro, na criação de normas jurídicas sobre os diversos negócios, e o segundo, na aplicação dessas normas, devem procurar conservar, em qualquer um dos três planos - existência, validade e eficácia-, o máximo possível do negócio jurídico realizado pelo agente.

O princípio da conservação consiste, pois, em procurar salvar tudo o que é possível num negócio jurídico concreto, tanto no plano da existência, quanto da validade, quanto da eficácia. Seu fundamento prende-se à própria razão de ser do negócio jurídico; sendo este uma espécie de fato jurídico, de tipo peculiar, isto é, uma declaração de vontade (manifestação de vontade a que o ordenamento jurídico imputa os efeitos manifestados como queridos), é evidente que, para o sistema jurídico, a autonomia da vontade produzindo auto-regramentos de vontade, isto é, a declaração produzindo efeitos, representa algo de juridicamente útil. A utilidade de cada negócio poderá ser econômico ou social, mas a verdade é que, a partir do momento em que o ordenamento jurídico admite a categoria negócio jurídico, sua utilidade passa a ser jurídico, visto vez que somente em cada negócio concreto é que adquire existência a categoria negócio jurídico.

A análise da situação e a tendência pela nulidade do negócio jurídico tratado neste artigo poderiam trazer a falsa conclusão de que uma das partes poderiam se beneficiar da nulidade, isto é, firmar pacto contendo como objeto uma prestação pecuniária em moeda estrangeira e em momento posterior requerer a sua nulidade com base no artigo 318 do Código Civil ou no Decreto Lei 857/69 se abstendo de cumprir sua prestação. O problema existirá se a outra parte já tiver adimplido com sua obrigação, observando que o contrato pode estipular diversas relações obrigacionais, o que geraria uma situação injusta.

Com o advento do novo Código Civil, esta situação de injustiça seria passível de correção não só pelo princípio da conservação, mas também pelas regras do artigo 182 e 884, ambos do Código Civil, que conferem "um mínimo de eficácia" à estipulação nula, evitando-se o enriquecimento ilícito. Observa-se que os julgados analisados foram proferidos com base no Código anterior, mas a conclusão não seria diferente, já que a doutrina, naquela oportunidade, aceitava o princípio da conservação e do enriquecimento sem causa.

A regra do artigo $182^{45}$ do Código Civil reproduz o artigo 158 do Código passado, não sendo, portanto, uma novidade, mas a ocorrência de um ato comissivo

${ }^{45}$ Art. 182 -Anulado o negócio jurídico, restituir-se-ão as partes ao estado em que antes se achavam,e, não sendo possível restituí-las, serão indenizadas com o equivalente. 
ou omissivo, mesmo que nulo, que desequilibra sem causa justificada os patrimônios das partes de uma relação obrigacional, acarretando uma vantagem patrimonial para um e uma desvantagem patrimonial para outro, configura uma situação anômala passível de interposição de uma ação de repetição, hoje positivada pelo artigo 884 do Código Civil.

Ressalta-se que os requisitos para a caracterização do enriquecimento ilícito são: ato comissivo ou omissivo; desequilíbrio desmedido e injusto entre as partes; prejuízo sem causa para uma das partes. Observa-se que tais requisitos são inteiramente diferentes dos requisitos caracterizadores da responsabilidade civil.

A caracterização do enriquecimento sem causa, segundo o Professor Português Mário Júlio de Almeida Costa ${ }^{46}$, é derivado, além dos três requisitos positivos, de três requisitos negativos. Como requisitos positivos citam: 1) enriquecimento (enriquecimento da pessoa obrigada à restituição); 2) suporte do enriquecimento por outrem ( um enriquecimento à custa de um empobrecimento); 3) correlação entre o enriquecimento e o suporte deste ( conexão entre o enriquecimento e o sacrifício econômico do outro). Como requisitos negativos citam: 1) ausência de causa legítima (inexistência de causa jurídica que justifique o deslocamento patrimonial); 2) ausência de outro meio jurídico (não se pode alegar enriquecimento sem causa quando há outro meio de ser indenizado ou ressarcido); 3) ausência de preceito legal que negue o direito à restituição.

Retornando ao problema levantado neste artigo, a nulidade da estipulação do pagamento em moeda estrangeira acarretaria a nulidade de toda a relação contratual, mas, se uma das partes tiver cumprido com sua prestação e a outra usufruída da situação, deverá e poderá aquela requerer a restituição, que não poderá ser superior ao empobrecimento sem causa suportado.

No exemplo dado, referente a um contrato de locação de imóvel firmado no Brasil, cujo aluguel é fixado em moeda estrangeira, ao contrário do exposto na teoria da viabilidade, a conclusão é pela sua nulidade, em conformidade com a regra do artigo 318 e 166, VII do Código Civil. O locador, caso não tenha recebido o aluguel, após o uso do inquilino e a declaração de nulidade, poderá pedir a restituição provando: a) enriquecimento do inquilino (usou da coisa locada); b) empobrecimento do locador (deixou de obter renda originária do bem locado); c) conexão entre o enriquecimento e o empobrecimento (não pagamento do aluguel pelo fato de nulidade contratual); d) inexistência de causa que justifique o enriquecimento de um e o empobrecimento de outro (o locador almeja a retribuição pela locação); e) ausência de outro meio jurídico ( única forma de corrigir a injustiça - artigo 886 do Código Civil); f) inexistência de vedação legal à restituição do indevidamente auferido.

${ }^{46}$ Vide Direto das Obrigações, Almedina, 2004, páginas 450/462. 
Existem certos casos que o objeto da restituição não pode ser realizado pelo fato de ter ocorrido perecimento ou consumo deste, levando o empobrecido a realizar a repetição pelo valor do bem (artigo 884, parágrafo único). No exemplo do contrato de locação, cujo locatário, que se encontra na posse do imóvel, se recusa ao pagamento do aluguel por ser convencionado em moeda estrangeira, fica impossível a restituição por parte do inquilino da vantagem que auferiu com o uso do imóvel, que é consumível. O que poderá restituir sem dúvida alguma seria a equivalência pecuniária pelo uso (vantagem) experimentado ${ }^{47}$.

A análise apresentada, contrapondo a tese da viabilidade, como não poderia deixar de ser, foi desenvolvida em torno da Legislação anterior ao código de 2002. A vigência do artigo 318 do Código Civil só reforça os argumentos levantados neste item, que declara expressamente a nulidade da estipulação tratada e veda a compensação da diferença entre o valor da moeda estrangeira e o da moeda nacional. Ora, o cumprimento da obrigação estipulada em contrato deste tipo, mesmo que o pagamento se dê em moeda nacional, implica infração à regra da compensação.

Conforme o visto, a solução ou reparação das possíveis injustiças se daria por intermédio do instituto do enriquecimento sem causa, existente e aceito no ordenamento anterior, embora que regulamentado no Código Civil de 2002.

Logo, se configura inviável defender, face a nossa legislação anterior e a vigente, a tese da viabilidade de um contrato firmado no Brasil e a ser cumprido no mesmo local por partes estabelecidas no território brasileiro ter como objeto prestação de pagar moeda estrangeira.

\section{F CONCLUSÃo}

A análise das conclusões obtidas com a pesquisa, que trata da viabilidade ou inviabilidade de contrato firmado no Brasil e a ser cumprido em nosso País por partes estabelecidas no território brasileiro ter como objeto prestação de pagar moeda

\footnotetext{
${ }^{47}$ O Professor Português COSTA (2004. P450-451):

“ Observe-se, além disso, que a vantagem em que o enriquecimento consiste se mostra susceptível de ser encarada sob dois ângulos: o do enriquecimento real, que corresponde ao valor objectivo e autônomo da vantagem adquirida; e do enriquecimento patrimonial, que reflecte a diferença, para mais, produzida na esfera econômica do enriquecido e que resulta da comparação entre a sua situação efectiva (situação real) e aquela em que encontraria se a deslocação se não houvesse verificado (situação hipotética)."

"Ora as referidas concepções podem conduzir a quantitativos muito diversos. Imagine-se que A usa ou consome uma certa coisa de B. O enriquecimento real será apreciado através do valor objectivo da utilização ou consumo dessa coisa, independentemente dos reflexos que teve no patrimônio de A. Pelo contrário, com vista à determinação do enriquecimento patrimonial, importa averiguar tais repercussões concretas, podendo chegar-se a um resultado inferior ou superior ao cumprimento."
} 
estrangeira, e expostas neste artigo ao longo dos itens dissertados podem ser apresentadas nos seguintes pontos:

1) O plano da validade difere do da eficácia, pois o negócio jurídico pode ser válido e ineficaz ${ }^{48}$, já a recíproca não é verdadeira. Isto é, salvo raras exceções $^{49}$, não pode existir negócio jurídico inválido, mas eficaz. A questão da validade não se confunde com a nulidade, mas o negócio inválido é nulo ou anulável.É neste prisma que devemos analisar o negócio jurídico proposto.

2) A exteriorização do negócio jurídico, conhecida como a forma do contrato, no entanto não se pode confundir com as formalidades, que também têm importância no plano da validade, caso haja preterição de algo prescrito ou não defeso em lei. As formalidades, no entanto, transcendem a forma, pois constituem requisitos acessórios de validade e o descumprimento daquelas tornam o negócio jurídico nulo, sendo inválido, mesmo que a forma exigida tenha sido obedecida.

3) Não se vislumbra que a fixação de uma estipulação, pagamento em moeda estrangeira de contrato firmado e a ser cumprido no Brasil, seja uma questão de forma ou formalidade, por dois aspectos básicos: a um, porque não se está discutindo a maneira de exteriorização do negócio relatado; a outro, porque a fixação de pagamento em moeda estrangeira não se configura um pacto acessório, nem uma solenidade. $\mathrm{O}$ assunto, na opinião deste articulista, encontra-se tratado no artigo 166, inciso VII da nossa lei substantiva, pois declara que é nulo o negócio jurídico quando: VII- a lei taxativamente declarar nulo, ou proibir-lhe a prática, sem cominar sanção. Logo a invalidade do negócio jurídico tratado poderia ser fundamentada neste plano.

4) Há uma corrente importante do STJ que defende a teoria da viabilidade dos negócios jurídicos celebrados em moeda estrangeira, desde que o cumprimento da prestação se dê em moeda corrente nacional. Para os julgados apresentados, a correta exegese do artigo $1^{\circ}$. Do Decreto -Lei $857 / 69$ é que a nulidade do pactuado só ocorre se o credor exigir o cumprimento do pactuado em moeda estrangeira.

5) O pagamento pactuado em moeda estrangeira, mas pago em moeda nacional, após a realização da devida conversão não pode ser considerado em face das normas anteriores ao Código Civil de 2002, pois a execução

\footnotetext{
${ }^{48}$ Como exemplo de negócio jurídico válido mas ineficaz são as obrigacionais condicionais suspensivas.

${ }^{49}$ Exemplo de negócio jurídico inválido, mas que gera efeito: Exemplo: Casamento de dois irmãos (artigo 1561 do Código Civil).
} 
do contrato em moeda nacional, mesmo que firmado em moeda estrangeira, não afasta a nulidade preconizada, o que torna a estipulação inválida.

6) Aceitar que é válido o negócio jurídico se o pagamento se der em moeda corrente nacional, tendo como parâmetro a moeda estrangeira, é indubitavelmente utilizar a variação da moeda estrangeira como indexador, fato que acarretaria também a nulidade da avença.

7) A oposição aos três argumentos levantados no item anterior leva o hermeneuta a concluirpela inviabilidade, já que existe norma expressa que veda a estipulação da prestação em moeda estrangeira e mesmo que o pagamento ocorra em moeda nacional não muda a ordem emanada na norma, pois a sua permissão implicaria no mínimo numa indexação do objeto da prestação à variação cambial, representada pela cotação da moeda alienígena.

8) Retornando ao problema levantado neste artigo, a nulidade da estipulação do pagamento em moeda estrangeira acarretaria a nulidade de toda a relação contratual, mas, se uma das partes tiver cumprido com sua prestação e a outra usufruída da situação, deverá e poderá aquela requerer a restituição, que não poderá ser superior ao empobrecimento sem causa suportado.

9) Existem certos casos que o objeto da restituição não pode ser realizado pelo fato de ter ocorrido perecimento ou consumo deste, levando o empobrecido a realizar a repetição pelo valor do bem (artigo 884, parágrafo único).

0) Logo, se configura inviável defender, face a nossa legislação anterior e a vigente, a tese da viabilidade de um contrato firmado no Brasil e a ser cumprido no mesmo local por partes estabelecidas no território brasileiro ter como objeto prestação de pagar moeda estrangeira.

\section{Bibliografia}

AZEVEDO, Antônio Junqueira de. Negócio jurídico: existência, validade e eficácia, 4.ed. São Paulo: Saraiva, 2002.

BEVILAQUA, Clovis. Código Civil dos Estados Unidos do Brasil comentado. vol. 01. Rio de Janeiro: Paulo de Azevedo, 1953.

. Teoria geral do Direito Civil. 7. ed. Rio de Janeiro: Paulo de Azevedo, 1955.

BOBBIO, Noberto. Teoria do ordenamento jurídico. Trad. Cláudio de Cicco e Maria Celeste C.J. Santos. Brasília: Polis, 1989.

A era dos direitos. Trad. Carlos Nelson Coutinho. Rio de Janeiro: Campus, 1992.

BONAVIDES, Paulo. Curso de Direito Constitucional. 4.ed. São Paulo: Malheiros, 1993. 
CLAUS, Wilhelm Canaris. Pensamento sistemático e conceito de sistema na ciência do direito. Trad. 3. ed. por Antônio Menezes Cordeiro. Lisboa: Fundação Calouste Gulbenkian, 2002.

COELHO, Fábio Ulhoa. Curso de Direito Civil: parte geral. vol.1, São Paulo: Saraiva, 2003.

COSTA, Mário Júlio de Almeida. Direito das obrigações. 9. ed. Lisboa: Almedina, 2004.

FALCÃO, Raimundo Bezerra. Hermenêutica. São Paulo: Malheiros, 1997.

GONÇALVES, Carlos Roberto. Direito Civil brasileiro. Vol. III. São Paulo: Saraiva, 2004.

PEREIRA, Caio Mário da Silva. Instituições de Direito Civil. vol II. São Paulo: Forense, 2003.

REALE, Miguel. Lições Preliminares de Direito. 15. ed. São Paulo: Saraiva, 1987. ROCHA, José de Albuquerque. Estudos sobre o poder judiciário. São Paulo: Malheiros, 1995.

RODRIGUES, Silvio. Direito Civil: parte geral. vol.1. 32. ed. São Paulo: Saraiva, 2002.

ROSAS, Roberto Rosas. Direito processual constitucional. São Paulo: RT, 1997. RUGGIERO, Roberto de. Instituições de Direito Civil. vol.1. Trad. 6. ed. italiana, por Paolo Capitanio. Campinas: Bookseller, 1999.

TEPEDINO, Gustavo. BARBOZA, Heloisa Helena. MORAES, Maria Celina Bodin de. Código Civil interpretado conforme a Constituição da República, vol.1. São Paulo: Renovar, 2004.

VASCONCELOS, Pedro Pais de. Teoria geral do Direito Civil. 3.ed. Lisboa: Almedina, 2003.

VENOSA, Silvio de Salvo. Direito Civil: parte geral. vol.1. 6. ed. São Paulo: Atlas, 2006.

WALD, Arnoldo. O novo direito monetário. 2. ed. São Paulo: Malheiros, 2002. 


\title{
Obligation OF PAYMENT IN FOREIGN CURRENCY
}

\begin{abstract}
After effective conversion, payment which was contracted on foreign currency but was paid in national currency can not be considered due to the rules of the 2002 Civil Code. Executing the contract in national currency, even when agreed on foreign currency does not avert the condition of nulity preconized by article 318 of such Code. The claim of damages brought about the invalidity of stipulation may be repaired relying on enrichment without a cause.
\end{abstract}

Key words: Obligation. Foreign currency. Nulity. 